\title{
KAJIAN ETNOBOTANI TUMBUHAN OBAT SUKU DAYAK LUNDAYEH DI DESA KALIAMOK KECAMATAN MALINAU UTARA KABUPATEN MALINAU SEBAGAI BOOKLET UNTUK MASYARAKAT
}

\section{Study of Ethnobotany of Medicinal Plants at Dayak Lundayeh Tribe in North Malinau, Malinau as a Booklet for Community}

\author{
Ade Setiawan $^{\mathrm{a}^{*}}$, Listiani $^{\mathrm{a}}$, Fadhlan Muchlas Abrori $^{\mathrm{a}}$
}

a Program Studi Pendidikan Biologi, Universitas Borneo Tarakan, Tarakan, Kalimantan Utara

"Corresponding author: Jl. Amal Lama, Tarakan Timur, Tarakan, Kalimantan Utara, 77123, Indonesia. E-mail: setiawanade552@gmail.com

\begin{abstract}
Abstrak
Penelitian ini bertujuan untuk mengetahui jenis-jenis tumbuhan obat yang digunakan oleh suku Dayak Lundayeh dan untuk mengetahui kualitas booklet tumbuhan obat dilihat dari segi kelayakan. Jenis penelitian ini adalah penelitian dan pengembangan (Research and Development) dengan model pengembangan Borg \& Gall (1983) yang dilakukan sampai tahap ke 7. Hasil penelitian menunjukkan bahwa terdapat 21 tumbuhan yang digunakan oleh suku Dayak Lundayeh sebagai obat dan tumbuhan tersebut terbagi dalam 13 famili. Dari 13 famili yang digunakan sebagai obat, tumbuhan dari famili Asteraceae dan family Zingiberaceae yang paling banyak digunakan. Hasil dari identifikasi jenis tumbuhan obat, kemudian dikembangkan menjadi booklet. Selanjutnya dilakukan validasi terhadap booklet oleh ahli materi, ahli media dan ahli bahasa. Hasil penilaian ahli materi mendapatkan persentase kelayakan 93,3\% dengan kriteria sangat layak, ahli media mendapatkan persentase $85 \%$ dengan kriteria layak, dan ahli bahasa mendapatkan persentase 93,3\% dengan kriteria sangat layak. Pada uji lapangan awal mendapatkan nilai persentase kelayakan 98,8\% dengan kriteria sangat layak sedangkan pada uji lapangan utama mendapatkan nilai persentase kelayakan sebesar 99,55\% dengan kriteria sangat layak.
\end{abstract}

Kata kunci: Booklet, Dayak Lundayeh, Etnobotani, Tumbuhan Obat

\section{Abstract}

This research is aimed to find out the medicinal plants of Dayak Lundayeh and to know the feasibility of the developed medicinal plant booklet. This is research and development study using Borg \& Gall (1983) model that conducted to the seventh step. The result shows that there are 21 medicinal plant species of Dayak Lundayeh that are categorized in 13 Families. Species form Asteraceae and Zingiberaceae are mostly used as medicine. The result of identification of medicinal plants was developed as a booklet. Then, the developed booklet is validated by material expert, media expert, and language expert. Material expert giving scores with percentage of $93 \%$ that is categorized as very adequate, validation of media expert reaches $85 \%$ and categorized as adequate, and language expert scores the booklet with percentage of 93\% (Very adequate). In addition, the result of preliminary field test and main field test show that the booklet is categorized as very adequate with percentage of 98,8\% and 99,55\% respectively.

Kevwords: Booklet, Davak Lundaveh, Ethnobotany, Medicinal Plants 


\section{Pendahuluan}

Indonesia merupakan negara tropis yang memiliki biodiversitas yang tinggi. Salah satu biodiversitas yang terdapat di Indonesia adalah Kingdom Plantae (tumbuhan) (Suhartini, 2009). Jumlah Kingdom Plantae yang diperkirakan terdapat di Indonesia terdiri dari 42.384 jenis (BAPPENAS, 2016). Indonesia memiliki suku dan budaya yang beragam yang ditandai dengan masih banyaknya unsur-unsur tradisional dalam kehidupan sehari-hari masyarakatnya. Salah satu unsur tradisional yang masih ada dimasyarakat adalah pemanfaatan tumbuhan yang ada disekitarnya. Pemanfaatan tumbuhan oleh masyarakat bukan hanya untuk keperluan ekonomi dan pangan tetapi dapat dimanfaatkan sebagai obat (Rahayu et al., 2006; Listiani \& Abrori, 2019).

Tumbuhan obat merupakan salah satu keanekaragaman hayati yang terdapat di Indonesia yang ditemukan di Kabupaten Malinau, Kalimantan Utara. Kabupaten Malinau memiliki berbagai jenis tumbuhan yang dimanfaatkan masyarakat sebagai obat. Berdasarkan penelitian yang telah dilakukan oleh Karmilasanti \& Supartini (2011) terdapat 32 jenis tumbuhan obat yang dimanfaatkan masyarakat di Desa Setulang, Kabupaten Malinau. Salah satu daerah di Kabupaten Malinau yang masih memanfaatkan tumbuhan sebagai obat selain Desa Setulang adalah Desa Kaliamok.

Berdasarkan wawancara yang telah dilakukan peneliti dengan 3 orang masyarakat di Desa Kaliamok, diperoleh informasi bahwa masyarakat Desa Kaliamok khususnya Suku Dayak Lundayeh masih menggunakan tumbuhan sebagai obat. Mereka memperoleh tumbuhan tersebut dari hutan dan disekitar Desa Kaliamok. Pengetahuan mengenai penggunaan tumbuhan sebagai obat mereka dapatkan berdasarkan pengetahuan dari nenek moyang. Banyaknya potensi tumbuhan obat di Desa Kaliamok, berbanding terbalik dengan ketersediaan data dan informasi tentang jenis-jenis tumbuhan yang dimanfaatkan oleh masyarakat. Pengenalan tumbuhan obat di Desa Kaliamok hanya diwariskan secara oral sehingga pengetahuan tersebut banyak yang tidak terdokumentasi dan dikhawatirkan akan hilang seiring dengan perkembangan zaman.

Salah satu cara agar pengetahuan tersebut dapat terdokumentasi dan tidak hilang adalah dengan mencantumkan ke dalam media seperti booklet yang dapat digunakan sebagai media untuk memperkenalkan tumbuhan obat di Desa Kaliamok. Booklet memiliki beberapa manfaat antara lain isinya mudah dimengerti, biaya relative murah, lebih tahan lama, menarik dan sangat efektif digunakan dalam meningkatkan pengetahuan (Fitriastutik, 2010; Abrori et al., 2016). Booklet sangat baik digunakan sebagai media sosialisasi mengenai kesehatan untuk meningkatkan pengetahuan, baik siswa maupun masyarakat. Berdasarkan penelitian yang dilakukan oleh Fitriastutik (2010), hasil penelitiannya menunjukkan bahwa booklet efektif digunakan sebagai media dalam meningkatkan pengetahuan siswa mengenai karies gigi. Selain itu, penelitian yang dilakukan oleh Agustin (2014) menunjukkan bahwa booklet efektif digunakan sebagai media dalam meningkatkan pengetahuan masyarakat.

\section{Metode Penelitian}

\section{Material dan metode}

Jenis penelitian yang digunakan adalah penelitian dan pengembangan (Research and Development). Research and Development (R\&D) merupakan suatu metode yang digunakan untuk menemukan, mengembangkan dan menguji produk (Sugiyono, 2015). Prosedur penelitian dan pengembangan mengikuti model yang dikembangkan Borg \& Gall (1983). Model ini terdiri dari 10 tahapan yaitu: 1) Penelitian dan pegumpulan informasi, 2) Perencanaan, 3) Pengembangan format produk awal, 4) Uji lapangan awal, 5) Revisi produk 


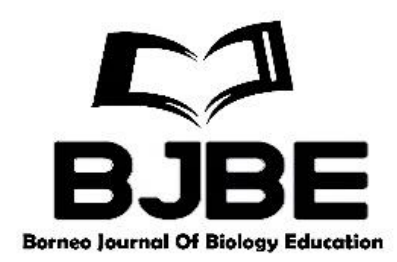

utama, 6) Uji lapangan utama, 7) Revisi produk operasional, 8) Uji lapangan operasional 9) Revisi produk akhir, 10) Desiminasi dan Implementasi (Borg \& Gall, 1983).

Pada penelitian ini akan dilakukan sampai pada tahap ke 7 yaitu tahap revisi produk operasional kemudian dilanjutkan dengan pembuatan produk akhir. Pada tahap 7, produk dapat digunakan apabila skor yang diberikan oleh para ahli dan masyarakat mencapai $76 \%$.

\section{Instrumen Pengumpulan Data}

Instrumen yang digunakan adalah lembar wawancara, lembar kuesioner (angket) pengetahuan masyarakat, lembar identifikasi, lembar validasi produk dan lembar angket respon masyarakat. Berikut penjabaran dari instrumen pengumpulan data yang digunakan dalam penelitian ini:

1. Lembar wawancara

Lembar wawancara yang dibuat berisi beberapa pertanyaan seperti nama lokal tumbuhan, bagian atau organ tumbuhan yang digunakan, cara mengolah, khasiat dan sumber diperoleh.

2. Lembar angket

Lembar angket pengetahuan masyarakat yang dibuat berisi pertanyaan mengenai tumbuhan obat mulai dari pernah mendengar, melihat, mengkonsumsi dan menggunakan sebagai obat.

3. Lembar identifikasi tumbuhan

Lembar identifikasi yang dibuat berisi tentang gambar yang disertai dengan nama klasifikasi dan ciri-ciri tumbuhan. Identifikasi mengacu kepada buku Van Steenis (2006), Glimn-Lacy \& Kaufman (2006), dan Bell (2001).

4. Lembar validasi

Lembar validasi digunakan untuk mendapat data mengenai pendapat para ahli terhadap booklet yang disusun oleh peneliti. Produk divalidasi oleh ahli yang berkompeten dalam hal produk yang dikembangkan, yaitu: ahli media, ahli materi dan bahasa sebelum dilakukan uji coba. Lembar validasi ahli media digunakan untuk menilai booklet dari aspek desain kulit booklet dan desain isi booklet. Lembar validasi ahli materi bertujuan untuk menilai booklet dari aspek kelayakan isi dan kelayakan penyajian. Lembar validasi ahli bahasa bertujuan untuk menilai booklet dari aspek ketepatan penggunaan bahasa.

5. Lembar angket respon

Lembar angket respon masyarakat bertujuan untuk menilai booklet dari aspek kemudahan dan kemenarikan. Angket ini dinilali oleh masyarakat sebagai pengguna.

\section{Analisis Data}

Data hasil dari validasi oleh ahli media, ahli materi dan ahli bahasa terhadap media yang dikembangkan berupa data kualitatif dan kuantitatif. Data kualitatif berupa kritik dan saran yang diberikan oleh ahli media, ahli materi dan ahli bahasa akan dijadikan pedoman dalam perbaikan media yang dikembangkan. Sedangkan data kuantitatif yang diperoleh dari penilaian ahli media, ahli materi dan ahli bahasa dianalisis menggunakan penilaian skor standar dari Riduwan (2015). Kriteria penilaian ahli menggunakan skala Likert dengan 5 interval (Tabel 1). 


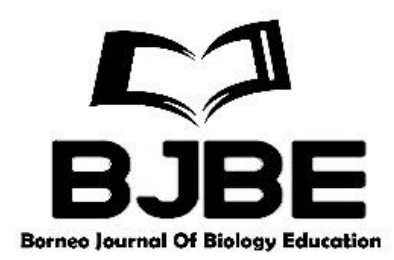

Tabel 1. Skala Penlialaian Ahli (Validator)

\begin{tabular}{llc}
\hline \multicolumn{1}{c}{ Deskripsi } & Kriteria & Skor \\
\hline $\begin{array}{l}\text { Konten dari booklet tidak sesuai dan tidak saling } \\
\text { terkait, format dan bahasa yang digunakan pada } \\
\text { booklet tidak sesuai. }\end{array}$ & 1 \\
$\begin{array}{l}\text { Sebagian besar konten dari booklet tidak sesuai dan } \\
\text { tidak saling terkait, format dan bahasa yang digunakan } \\
\text { pada booklet tidak sesuai. }\end{array}$ & 2 \\
$\begin{array}{l}\text { Separuh konten dari booklet sesuai dan saling terkait, Cukup } \\
\text { format dan bahasa yang digunakan } \\
\text { pada booklet sesuai. }\end{array}$ & 3 \\
$\begin{array}{l}\text { Sebagian besar konten dari booklet sesuai dan saling } \\
\text { terkait, format dan bahasa yang digunakan pada } \\
\text { booklet sesuai. }\end{array}$ & \\
$\begin{array}{l}\text { Semua konten dari booklet sesuai dan saling terkait, Sangat Baik } \\
\text { format dan bahasa yang digunakan } \\
\text { pada booklet sesuai. }\end{array}$ & \\
\hline
\end{tabular}

(Modifikasi dari Riduwan, 2015)

Untuk memperoleh persentase kelayakan booklet digunakan rumus dari Purwanto (2009). Berikut penjabaran dari rumus yang digunakan:

$$
\mathrm{NP}=\frac{R}{S M} \times 100 \%
$$

Keterangan :

NP : Persentase kelayakan

$\mathrm{R} \quad$ : Skor yang diperoleh

SM : Skor maksimal

Setelah diperoleh hasil perhitungan persentase kelayakan, kemudian hasil perolehan nilai akan di interpretasikan menurut tabel kriteria penilaian validator pada Tabel 2 .

Tabel 2. Kriteria Penilaian Validator

\begin{tabular}{lll}
\hline & \multicolumn{1}{c}{ Persentase } & Kriteria \\
\hline $86 \%-100 \%$ & & Sangat layak \\
$76 \%-85 \%$ & Layak & \\
$60 \%-75 \%$ & Cukup layak & \\
$55 \%-59 \%$ & Kurang layak & \\
$<54 \%$ & Sangat tidak layak & \\
\hline
\end{tabular}

Sumber: Purwanto, 2009

Setelah dilakukan uji validasi, dilakukan uji lapangan dan dinilai respon dari masyarakat terkait booklet yang dikembangkan. Data hasil dari respon masyarakat terhadap media yang dikembangkan berupa data kualitatif dan kuantitatif. Data kualitatif berupa kritik dan saran yang diberikan oleh masyarakat akan dijadikan masukan dalam perbaikan media yang dikembangkan. Sedangkan data kuantitatif yang diperoleh dari penilaian masyarakat akan dianalisis menggunakan penilaian skor standar dari Riduwan (2015). Kriteria penilaian menggunakan skala Likert dengan 5 interval. 


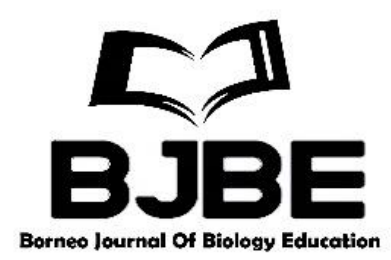

Tabel 3. Skala Penlialaian Ahli (Validator)

\begin{tabular}{|l|l|c|}
\hline \multicolumn{1}{|c|}{ Deskripsi } & \multicolumn{1}{c|}{ Kriteria } & Skor \\
\hline Konten isi pada booklet tidak jelas dan tidak menarik. & Sangat Kurang & 1 \\
\hline $\begin{array}{l}\text { Sebagian besar konten isi pada booklet tidak jelas dan } \\
\text { tidak menarik. }\end{array}$ & Kurang & 2 \\
\hline Separuh konten isi pada booklet jelas dan menarik. & Cukup & 3 \\
\hline $\begin{array}{l}\text { Sebagian besar konten isi pada booklet jelas dan } \\
\text { menarik. }\end{array}$ & Baik & 4 \\
\hline Semua konten isi pada booklet jelas dan menarik. & Sangat Baik & 5 \\
\hline
\end{tabular}

(Modifikasi dari Riduwan, 2015)

Untuk memperoleh persentase kelayakan booklet digunakan rumus dari Purwanto (2009).

Berikut penjabaran dari rumus yang digunakan:

$$
\mathrm{NP}=\frac{R}{S M} \times 100 \%
$$

Keterangan :

NP : Persentase kelayakan

$\mathrm{R}$ : Skor yang diperoleh

SM : Skor maksimal

Persentase yang diperoleh kemudian dikategorikan dalam tabel kriteria pada tabel 4.

Tabel 4. Kriteria Interprestasi Respon Masyarakat

\begin{tabular}{|l|l|}
\hline \multicolumn{1}{|c|}{ Persentase } & \multicolumn{1}{c|}{ Kriteria } \\
\hline $86 \%-100 \%$ & Sangat layak \\
$76 \%-85 \%$ & Layak \\
$60 \%-75 \%$ & Cukup layak \\
$55 \%-59 \%$ & Kurang layak \\
$<54 \%$ & Sangat tidak layak \\
\hline
\end{tabular}

\section{Hasil dan Diskusi}

\section{Indentifikasi Jenis-Jenis Tumbuhan Obat}

Tumbuhan yang digunakan masyarakat sebagai obat terdiri dari 21 jenis tumbuhan yang terbagi menjadi 13 suku yaitu suku Acanthaceae, Araceae, Aristolochiaceae, Caricaceae, Crassulaceae, Fabaceae, Lamiaceae, Phyllanthaceae, Rubiaceae, Solonaceae dan Verbenaceae yang masing-masing terdiri dari 1 jenis tumbuhan, suku Asteraceae terdiri dari 3 jenis tumbuhan dan suku Zingiberaceae terdiri dari 7 jenis tumbuhan. Data tersebut diperoleh dari hasil wawancara yang telah dilakukan terhadap 20 orang masyarakat Suku Dayak Lundayeh di Desa Kaliamok (Tabel 5). 


\section{EII \\ BJBE}

Tabel 5. Jenis Tumbuhan Obat oleh Suku Dayak Lundayeh di Desa Kaliamok

\begin{tabular}{|c|c|c|c|c|c|c|c|c|}
\hline \multirow{2}{*}{ No } & \multicolumn{3}{|c|}{ Jenis Tumbuhan Obat } & \multirow{2}{*}{$\begin{array}{c}\text { Bagian yang } \\
\text { digunakan }\end{array}$} & \multirow{2}{*}{ Cara pengolahan } & \multirow{2}{*}{ Pengobatan } & \multirow{2}{*}{ Habitat } & \multirow{2}{*}{ Kandungan Kimia } \\
\hline & Nama Ilmiah & Suku & Nama Lokal & & & & & \\
\hline 1 & $\begin{array}{l}\text { Kalanchoe pinnata } \\
\text { (Lam.) Pers. }\end{array}$ & Crassulaceae & Babas & Daun & $\begin{array}{l}\text { Dihaluskan } \\
\text { kemudian } \\
\text { ditempel. }\end{array}$ & $\begin{array}{l}\text { Bengkak dan } \\
\text { bisul }\end{array}$ & $\begin{array}{l}\text { Tumbuhan } \\
\text { budidaya }\end{array}$ & $\begin{array}{l}\text { Zat Asam Lemon, Zat } \\
\text { Asam Apel,Vitamin C, } \\
\text { Quercetin-3-Diarabinoside, } \\
\text { Kaempferol-3-Glukoside } \\
\text { dan Tannin. }\end{array}$ \\
\hline 2 & $\begin{array}{l}\text { Capsicum frutescens } \\
\text { L. }\end{array}$ & Solanaceae & $\begin{array}{l}\text { Bua } \\
\text { Lade' }\end{array}$ & $\begin{array}{l}\text { Akar dan } \\
\text { buah }\end{array}$ & $\begin{array}{l}\text { Akarnya : } \\
\text { dicampurkan } \\
\text { dengan garam } \\
\text { kemudian di taruh } \\
\text { kedalam gigi. } \\
\text { Buahnya: } \\
\text { dipotong } \\
\text { kemudian } \\
\text { dioleskan ke } \\
\text { bagian } \\
\text { tubuh yang } \\
\text { tertinjak } \\
\text { paku }\end{array}$ & $\begin{array}{l}\text { Sakit gigi, } \\
\text { Terinjak paku } \\
\text { (luka) }\end{array}$ & $\begin{array}{l}\text { Tumbuhan } \\
\text { budidaya }\end{array}$ & $\begin{array}{l}\text { Kapsaisin, Kapsantin, } \\
\text { Karotenoid, Alkaloid, Asiri, } \\
\text { Resin, Vitamin (A dan C). }\end{array}$ \\
\hline 3 & Homalomena sp. & Araceae & Duli' & Daun & $\begin{array}{l}\text { Dihaluskan, } \\
\text { kemudian dibakar } \\
\text { sampai menjadi } \\
\text { abu, lalu dioleskan } \\
\text { kebagian tubuh } \\
\text { yang luka. }\end{array}$ & Luka & $\begin{array}{l}\text { Tumbuhan } \\
\text { liar }\end{array}$ & $\begin{array}{l}\text { Saponin, Flavonoid, Tanin } \\
\text { dan Polifenol. }\end{array}$ \\
\hline 4 & Ixora coccinea $\mathrm{L}$. & Rubiaceae & $\begin{array}{l}\text { Geri } \\
\text { Sarang }\end{array}$ & Bunga & $\begin{array}{l}\text { Langsung } \\
\text { digunakan, dengan } \\
\text { cara ditepukkan } \\
\text { pada kepala. }\end{array}$ & $\begin{array}{l}\text { Gatal pada } \\
\text { kepala }\end{array}$ & $\begin{array}{l}\text { Tumbuhan } \\
\text { budidaya }\end{array}$ & $\begin{array}{l}\text { Flavonoid, Saponin, Tannin, } \\
\text { Alkaloid dan } \\
\text { Steroid. }\end{array}$ \\
\hline 5 & $\begin{array}{l}\text { Blumea balsamifera } \\
\text { DC. }\end{array}$ & Asteraceae & Ipung & Daun & $\begin{array}{l}\text { Direbus kemudian } \\
\text { air rebusannya } \\
\text { diminum }\end{array}$ & $\begin{array}{l}\text { Malaria dan } \\
\text { sakit } \\
\text { perut }\end{array}$ & $\begin{array}{l}\text { Tumbuhan } \\
\text { liar }\end{array}$ & $\begin{array}{l}\text { Bomeol, Cineol, } \\
\text { Limonene, Minyak } \\
\text { Asiri, Asam Palmitin, } \\
\text { Myristin, Tannin dan } \\
\text { Glikosida. }\end{array}$ \\
\hline
\end{tabular}




\section{[II \\ BJBE}

\begin{tabular}{|c|c|c|c|c|c|c|c|c|}
\hline 6 & $\begin{array}{l}\text { Stacytarpheta } \\
\text { jamaicensis } \\
\text { (L.) Vahl. }\end{array}$ & Verbenaceae & Iyur kuda & Daun & $\begin{array}{l}\text { Direbus kemudian } \\
\text { air rebusannya } \\
\text { diminum }\end{array}$ & $\begin{array}{l}\text { Batuk dan } \\
\text { sakit } \\
\text { tenggorokan }\end{array}$ & $\begin{array}{l}\text { Tumbuhan } \\
\text { liar }\end{array}$ & $\begin{array}{l}\text { Glikosida Flavonoid dan } \\
\text { Alkaloid. }\end{array}$ \\
\hline 7 & $\begin{array}{l}\text { Orthosiphon spicatus } \\
\text { B.B.S. }\end{array}$ & Lamiaceae & $\begin{array}{l}\text { Kumis } \\
\text { Kucing }\end{array}$ & Daun & $\begin{array}{l}\text { Direbus kemudian } \\
\text { air rebusannya } \\
\text { diminum }\end{array}$ & $\begin{array}{l}\text { Tekanan, } \\
\text { diabetes dan } \\
\text { susah buang } \\
\text { air } \\
\text { kecil }\end{array}$ & $\begin{array}{l}\text { Tumbuhan } \\
\text { budidaya }\end{array}$ & $\begin{array}{l}\text { Orthosipon Glikosida, Zat } \\
\text { Samak, Minyak Asiri, } \\
\text { Minyak Lemak, Saponin, } \\
\text { Sapofonin, Garam Kalium, } \\
\text { Mioinositol dan Sinensetin. }\end{array}$ \\
\hline 8 & Curcuma longa L. & Zingiberaceae & Kunus & Rimpang & $\begin{array}{l}\text { Direbus kemudian } \\
\text { air rebusannya } \\
\text { diminum }\end{array}$ & Sakit perut & $\begin{array}{l}\text { Tumbuhan } \\
\text { budidaya }\end{array}$ & $\begin{array}{l}\text { Kurkumin, Minyak } \\
\text { Asiri, Resin, Oleoresin, } \\
\text { Desmetoksikurkumin, } \\
\text { Lemak, Protein dan } \\
\text { Kalsium. }\end{array}$ \\
\hline 9 & $\begin{array}{l}\text { Curcuma zedoaria } \\
\text { (Berg.) Rosc. }\end{array}$ & Zingiberaceae & $\begin{array}{l}\text { Liye' } \\
\text { budak }\end{array}$ & Rimpang & $\begin{array}{l}\text { Direbus kemudian } \\
\text { air rebusannya } \\
\text { diminum }\end{array}$ & $\begin{array}{l}\text { Penambah } \\
\text { nafsu } \\
\text { makan dan } \\
\text { mencegah } \\
\text { masuk } \\
\text { angin }\end{array}$ & $\begin{array}{l}\text { Tumbuhan } \\
\text { budidaya }\end{array}$ & $\begin{array}{l}\text { Cineole, Champane, } \\
\text { Zingiberane, Borneol, } \\
\text { Camphor, Curcumin, } \\
\text { Resin, Curcumol, Dan } \\
\text { Curdione. }\end{array}$ \\
\hline 10 & $\begin{array}{l}\text { Curcuma } \\
\text { xanthorrhiza } \\
\text { Roxb. }\end{array}$ & Zingiberaceae & Liye' bun & Rimpang & $\begin{array}{l}\text { Direbus kemudian } \\
\text { air rebusannya } \\
\text { diminum }\end{array}$ & $\begin{array}{l}\text { Penambah } \\
\text { nafsu } \\
\text { makan dan } \\
\text { mencegah } \\
\text { masuk } \\
\text { angin }\end{array}$ & $\begin{array}{l}\text { Tumbuhan } \\
\text { budidaya }\end{array}$ & $\begin{array}{l}\text { Kurkumin, Zat Tepung, } \\
\text { Glikosida, Protein, } \\
\text { Karbinol, Essoil, Serat } \\
\text { Dan Kalium Oksalat. }\end{array}$ \\
\hline 11 & $\begin{array}{l}\text { Zingiber } \\
\text { aromaticum } \\
\text { Val. }\end{array}$ & Zingiberaceae & $\begin{array}{l}\text { Liye' } \\
\text { fasut }\end{array}$ & Rimpang & $\begin{array}{l}\text { Direbus kemudian } \\
\text { air rebusannya } \\
\text { diminum }\end{array}$ & Maag & $\begin{array}{l}\text { Tumbuhan } \\
\text { budidaya }\end{array}$ & $\begin{array}{l}\text { Flavonoid, Saponin, Tanin } \\
\text { dan Minyak Asiri. }\end{array}$ \\
\hline 12 & $\begin{array}{l}\text { Curcuma aeruginosa } \\
\text { Roxb. }\end{array}$ & Zingiberaceae & $\begin{array}{l}\text { Liye' } \\
\text { item }\end{array}$ & Rimpang & $\begin{array}{l}\text { Direbus kemudian } \\
\text { air rebusannya } \\
\text { diminum }\end{array}$ & $\begin{array}{l}\text { Penambah } \\
\text { nafsu } \\
\text { makan dan } \\
\text { mencegah } \\
\text { masuk } \\
\text { angin } \\
\end{array}$ & $\begin{array}{l}\text { Tumbuhan } \\
\text { budidaya }\end{array}$ & $\begin{array}{l}\text { Minyak Asiri, Curcumol, } \\
\text { Kordione, Zat Pati, Damar, } \\
\text { Lemak, Tanin, Alkaloid, Zat } \\
\text { Pahit dan Saponin. }\end{array}$ \\
\hline 13 & $\begin{array}{l}\text { Curcuma mangga } \\
\text { Val. }\end{array}$ & Zingiberaceae & Liye' lisit & Rimpang & $\begin{array}{l}\text { Direbus kemudian } \\
\text { air rebusannya }\end{array}$ & $\begin{array}{l}\text { Penambah } \\
\text { nafsu }\end{array}$ & $\begin{array}{l}\text { Tumbuhan } \\
\text { budidaya }\end{array}$ & $\begin{array}{l}\text { Tanin, Kurkumin, } \\
\text { Amilum, Minyak Asiri, }\end{array}$ \\
\hline
\end{tabular}




\section{[II \\ BJBE}

\begin{tabular}{|c|c|c|c|c|c|c|c|c|}
\hline & & & & & diminum & $\begin{array}{l}\text { makan dan } \\
\text { mencegah } \\
\text { masuk } \\
\text { angin }\end{array}$ & & $\begin{array}{l}\text { Damar, Saponin, } \\
\text { Flavonoid, dan Protein. }\end{array}$ \\
\hline 14 & $\begin{array}{l}\text { Zingiber officinnale } \\
\text { Rosc. }\end{array}$ & Zingiberaceae & Liye' siya & Rimpang & $\begin{array}{l}\text { Direbus kemudian } \\
\text { air rebusannya } \\
\text { diminum }\end{array}$ & $\begin{array}{l}\text { Batuk dan } \\
\text { sakit } \\
\text { tenggorokan }\end{array}$ & $\begin{array}{l}\text { Tumbuhan } \\
\text { budidaya }\end{array}$ & $\begin{array}{l}\text { Gingerol, Zingiberene, } \\
\text { Karbohidrat, Minyak } \\
\text { Asiri dan Kurkumin. }\end{array}$ \\
\hline 15 & $\begin{array}{l}\text { Strobilanthes crispus } \\
\text { BI. }\end{array}$ & Acanthaceae & $\begin{array}{l}\text { Pecah } \\
\text { beling }\end{array}$ & Daun & $\begin{array}{l}\text { Direbus kemudian } \\
\text { air rebusannya } \\
\text { diminum }\end{array}$ & $\begin{array}{l}\text { Susah buang } \\
\text { air } \\
\text { kecil }\end{array}$ & $\begin{array}{l}\text { Tumbuhan } \\
\text { budidaya }\end{array}$ & $\begin{array}{l}\text { Saponin, Flavonoid, } \\
\text { Glikosida, Sterol, Golongan } \\
\text { terpen, lemak dan Mineral. }\end{array}$ \\
\hline 16 & Phyllanthus niruri L. & $\begin{array}{l}\text { Phyllanthacea } \\
\text { e }\end{array}$ & $\begin{array}{l}\text { Rumput } \\
\text { gendong } \\
\text { anak }\end{array}$ & Daun & $\begin{array}{l}\text { Direbus kemudian } \\
\text { air rebusannya } \\
\text { diminum }\end{array}$ & $\begin{array}{l}\text { Demam dan } \\
\text { mag }\end{array}$ & $\begin{array}{l}\text { Tumbuhan } \\
\text { liar }\end{array}$ & $\begin{array}{l}\text { Filantin, Hipofilantin, } \\
\text { Kalium, Damar dan Tanin. }\end{array}$ \\
\hline 17 & Cassia alata $\mathrm{L}$. & Fabaceae & Saga & Daun & $\begin{array}{l}\text { Dihaluskan } \\
\text { kemudian } \\
\text { dioleskan } \\
\text { pada bagian tubuh } \\
\text { yang sakit }\end{array}$ & $\begin{array}{l}\text { Gatal pada } \\
\text { kulit,panu } \\
\text { dan } \\
\text { kurap }\end{array}$ & $\begin{array}{l}\text { Tumbuhan } \\
\text { liar }\end{array}$ & $\begin{array}{l}\text { Antrakinon, Alkaloid, } \\
\text { Saponin, Tanin dan } \\
\text { Flavonoid. }\end{array}$ \\
\hline 18 & Carica papaya L. & Caricaceae & Sesila’ & Daun & $\begin{array}{l}\text { Direbus kemudian } \\
\text { air rebusannya } \\
\text { diminum }\end{array}$ & Malaria & $\begin{array}{l}\text { Tumbuhan } \\
\text { budidaya }\end{array}$ & $\begin{array}{l}\text { Alkaloid, Karpain, } \\
\text { Caricaksantin, Violaksantin, } \\
\text { Papain, Saponin dan } \\
\text { Flavonoid }\end{array}$ \\
\hline 19 & $\begin{array}{l}\text { Aristolochia } \\
\text { foveolata } \\
\text { Merr. }\end{array}$ & Aristoloceae & $\begin{array}{l}\text { Tabar } \\
\text { Kedayan }\end{array}$ & Akar & $\begin{array}{l}\text { Dikikis kemudian } \\
\text { direbus, lalu air } \\
\text { rebusannya } \\
\text { diminum. }\end{array}$ & $\begin{array}{l}\text { Sakit perut } \\
\text { dan anti } \\
\text { racun/ } \\
\text { mengatasi } \\
\text { segala jenis } \\
\text { bisa }\end{array}$ & $\begin{array}{l}\text { Tumbuhan } \\
\text { liar }\end{array}$ & $\begin{array}{l}\text { Alkaloid, Flavonoid, } \\
\text { Saponin, Tanin, } \\
\text { Terpeneoid dan Steroid. }\end{array}$ \\
\hline 20 & $\begin{array}{l}\text { Ageratum } \\
\text { conyzoides } \mathrm{L} .\end{array}$ & Asteraceae & $\begin{array}{l}\text { Udu' } \\
\text { buen }\end{array}$ & Daun & $\begin{array}{l}\text { Direbus kemudian } \\
\text { air rebusannya } \\
\text { diminum }\end{array}$ & $\begin{array}{l}\text { Demam dan } \\
\text { mag }\end{array}$ & $\begin{array}{l}\text { Tumbuhan } \\
\text { liar }\end{array}$ & $\begin{array}{l}\text { Asam Amino, } \\
\text { Organacid, Minyak Asiri } \\
\text { Kumarin, Stigmasterol, } \\
\text { Tanin, Sulfur dan } \\
\text { Potassium Chlorida. }\end{array}$ \\
\hline 21 & Eclipta $\mathrm{sp}$. & Asteraceae & Udu'saku & Daun & $\begin{array}{l}\text { Dihaluskan } \\
\text { kemudian } \\
\text { ditempel }\end{array}$ & $\begin{array}{l}\text { Terinjak } \\
\text { paku/ luka }\end{array}$ & $\begin{array}{l}\text { Tumbuhan } \\
\text { liar }\end{array}$ & $\begin{array}{l}\text { Isoflavonoids, } \\
\text { Phytosterol, Nicotine, } \\
\text { Ecliptine, Thiophene }\end{array}$ \\
\hline
\end{tabular}




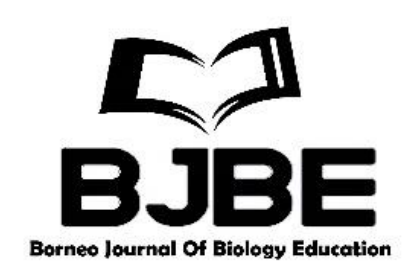

pada bagian tubuh

yang terinjak

paku. 


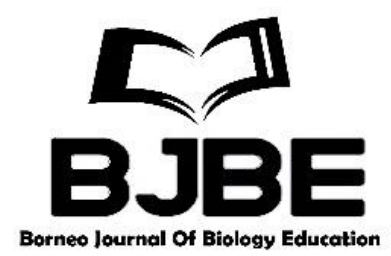

Hasil penelitian ini menunjukkan bahwa terdapat 21 jenis tumbuhan (Tabel 5) yang digunakan oleh masyarakat Suku Dayak Lundayeh sebagai obat. Tumbuhan obat tersebut terbagi menjadi 13 suku yang dirinci berdasarkan gambar 1 .

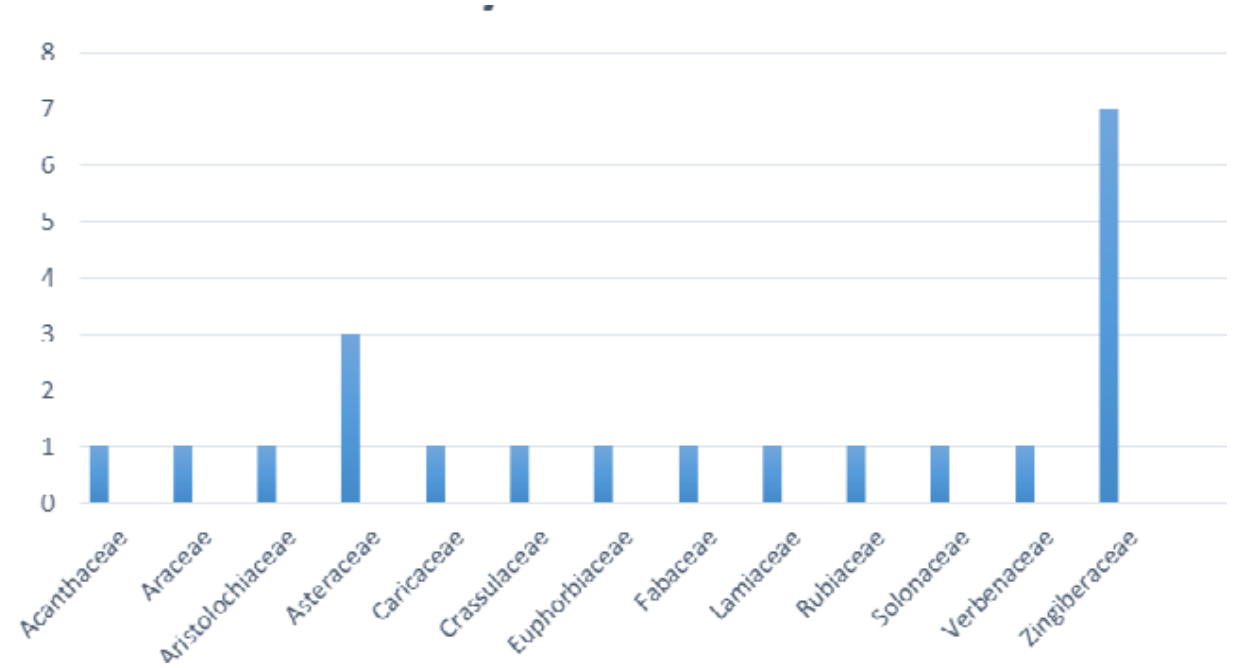

Gambar 1. Distribusi Suku Tumbuhan Obat

Gambar 1 menunjukkan bahwa suku atau famili yang paling banyak ditemukan di Desa Kaliamok adalah famili Zingiberaceae. Jenis tumbuhan yang tergolong dalam famili Zingiberaceae sering digunakan masyarakat karena tumbuhan tersebut selain dimanfaatkan sebagai obat oleh masyarakat tetapi juga dimanfaatkan sebagai bumbu untuk bahan masakan. Whasikah (2016) menyatakan bahwa famili Zingiberaceae memiliki banyak manfaat bagi masyarakat, selain sebagai bahan obat dan bumbu untuk bahan masakan, masyarakat juga memanfaatkannya sebagai tanaman hias, bahan kosmetik dan bahan minuman. Nurjannah et al. (2015) menyatakan bahwa famili Zingiberaceae banyak dimanfaatkan masyarakat dikarenakan famili tersebut sangat mudah dibudidayakan.

Informasi lain yang diperoleh selain jenis-jenis tumbuhan adalah organ tumbuhan yang dimanfaatkan masyarakat sebagai bahan obat sebagaimana ditunjukkan pada gambar 2 .

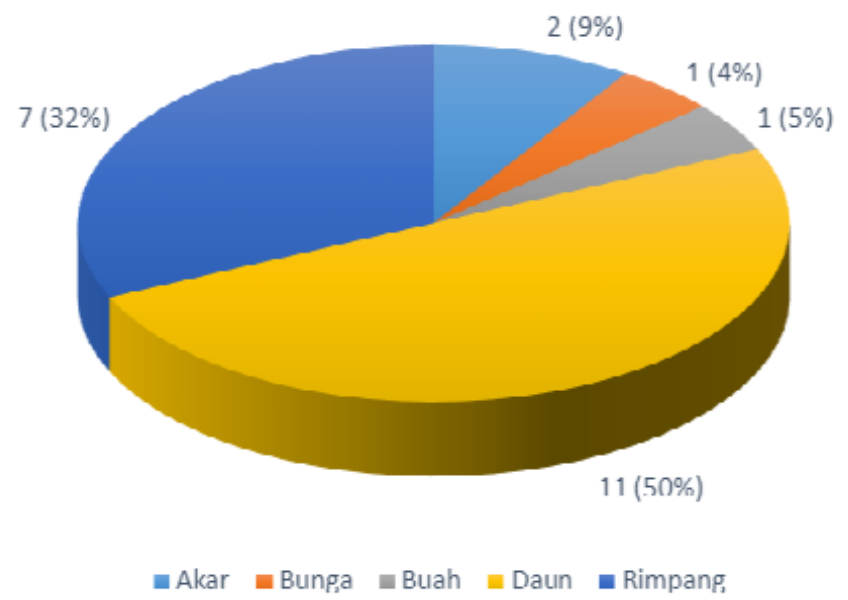

Gambar 2 Persentase Bagian Tumbuhan yang Digunakan 


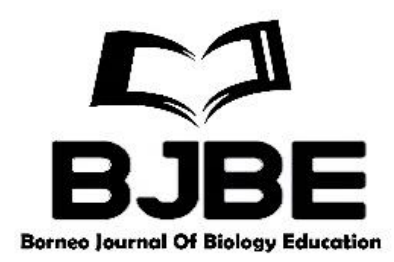

Organ tumbuhan yang digunakan masyarakat sebagai bahan obat adalah akar, bunga, buah, daun dan rimpang. Berbagai organ tersebut, organ tumbuhan yang paling banyak digunakan masyarakat sebagai bahan obat adalah daun (Gambar 2). Masyarakat banyak memanfaatkan daun sebagai bahan obat dikarenakan daun sangat mudah diperoleh dilingkungan sekitar Desa Kaliamok, selain itu daun sangat mudah diambil dibandingkan dengan bagian organ tumbuhan lainnya.

Selanjutnya, cara pengolahan tumbuhan berdasarkan resep nenek moyang Suku Dayak Lundayeh ditampilkan pada gambar 3.

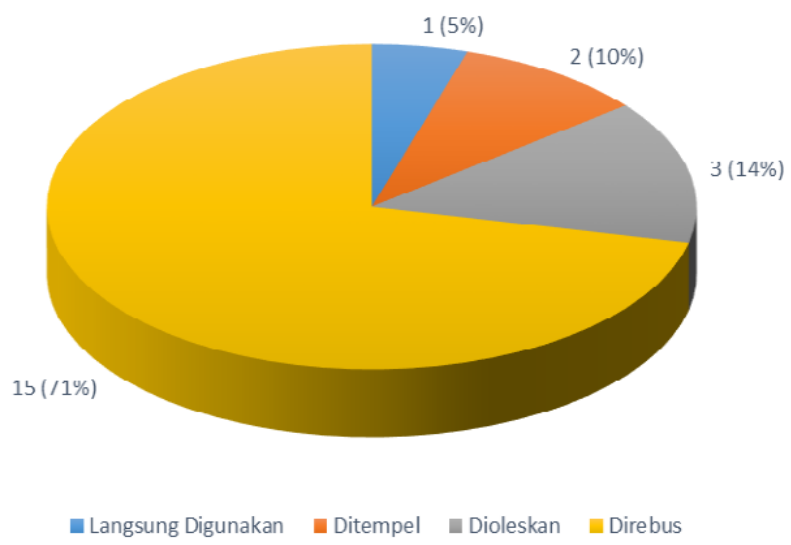

Gambar 3. Cara Pengolahan Tumbuhan Obat

Cara pengolahan tumbuhan obat oleh masyarakat tersebut berbeda-beda mulai dari langsung digunakan, ditempel, dioleskan dan direbus tergantung dari jenis penyakit yang diderita masyarakat. Jika penyakit yang diderita diluar tubuh maka cara pengolahannya berupa langsung digunakan, ditempel dan dioleskan. Jika penyakit yang diderita didalam tubuh maka cara pengolahannya dengan cara direbus. Sebagian besar cara pengolahan tumbuhan oleh masyarakat adalah dengan cara direbus (Gambar 3), hal tersebut dikarenakan penyakit yang diderita oleh sebagian besar masyarakat Suku Dayak Lundayeh berada didalam tubuh. Anna (2011) menyatakan bahwa merebus tumbuhan sangat baik dilakukan karena bertujuan untuk memindahkan zat-zat berguna dari tumbuhan kedalam air rebusan. Haryono et al. (2014) menyatakan bahwa masyarakat mempercayai pengolahan tumbuhan dengan cara direbus kemudian diminum maka penyakit yang mereka derita akan langsung sembuh dan reaksi dari rebusan tumbuhan tersebut sangat cepat jika dibandingkan dengan cara pengolahan yang lain.

Selanjutnya, mengenai bagaimana masyarakat Suku Dayak Lundayeh memperoleh tumbuhan tersebut yang dirinci berdasarkan gambar 4 .

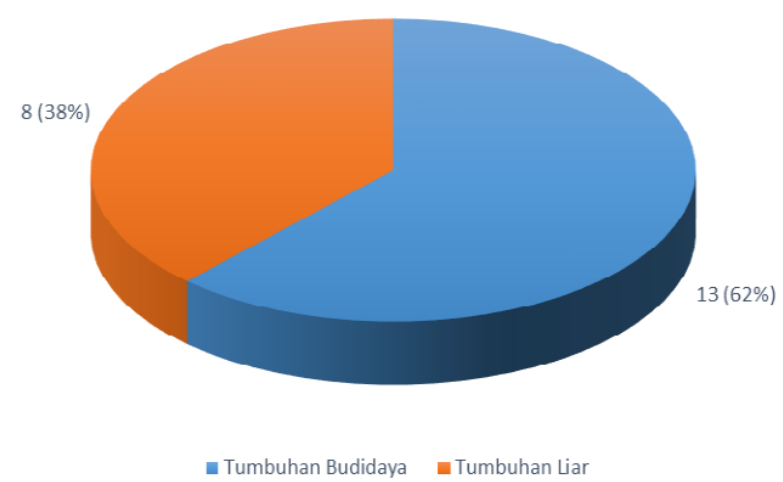

Gambar 4. Habitat Tumbuhan Obat 


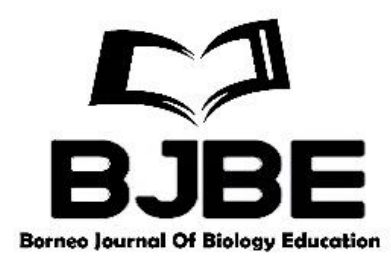

Sumber memperoleh tumbuhan obat tersebut terbagi menjadi 2 yaitu tumbuhan liar dan tumbuhan budidaya. Gambar 4 menunjukkan bahwa sebagian besar jenis tumbuhan obat yang digunakan adalah tumbuhan yang dibudidayakan. Banyaknya tumbuhan yang dibudidayakan oleh masyarakat agar mempermudah masyarakat untuk mengambil dan mengolah tumbuhan tersebut sehingga tidak membutuhkan waktu yang lama untuk mencari tumbuhan lagi disaat sakit. Syamsir (2015) menyatakan bahwa budidaya merupakan salah satu cara agar tumbuhan tersebut selalu ada setiap saat dan kapanpun ingin digunakan oleh masyarakat

\section{Validasi Ahli}

Media booklet disusun dengan tujuan untuk menjaga agar pewarisan pengetahuan tradisional mengenai tumbuhan obat tidak hilang. Selanjutnya, media booklet yang dikembangkan diuji kualitasnya yaitu dari segi kelayakan. Kelayakan booklet dengan judul "Kajian Etnobotani Tumbuhan Obat Dayak Lundayeh di Kalimantan Utara", didasarkan pada hasil validasi oleh para ahli dan uji coba pada masyarakat.

Pengembangan format produk awal dinilai oleh 3 orang ahli, yaitu ahli materi, media dan bahasa. Hasil validasi dari para ahli digunakan untuk menilai media booklet tersebut apakah sudah layak atau belum, jika sudah layak maka booklet dapat digunakan untuk uji lapangan awal. Berikut merupakan hasil validasi dari ahli materi yang dirinci berdasarkan Tabel 6.

Tabel 6. Hasil Validasi Ahli Materi

\begin{tabular}{|l|c|}
\hline \multicolumn{1}{|c|}{ Aspek } & Persentase \\
\hline Materi yang disajikan sesuai dengan tujuan & 100 \\
\hline Materi yang disajikan akurat atau sesuai dengan fakta & 80 \\
\hline Materi yang disajikan akurat atau sesuai dengan fakta & 100 \\
\hline $\begin{array}{l}\text { Bagian depan : Daftar isi memberikan gambaran mengenai isi booklet yang diikuti } \\
\text { dengan nomor halaman kemunculan }\end{array}$ & 100 \\
\hline $\begin{array}{l}\text { Bagian teks : Materi yang disajikan dalam booklet memuat gambar, foto dan } \\
\text { ilustrasi yang menarik dan mudah dipahami }\end{array}$ & 80 \\
\hline $\begin{array}{l}\text { Bagian belakang : 1. Daftar pustaka menggambarkan bahan rujukan yang } \\
\text { digunakan dalam penulisan booklet. 2. Daftar istilah (glosarium) berisikan } \\
\text { kumpulan istilah penting beserta penjelasannya. }\end{array}$ & 100 \\
\hline \multicolumn{1}{|c|}{ Total } & \\
\hline \multicolumn{1}{|c|}{} & \\
\hline
\end{tabular}

Ahli materi memvalidasi aspek kelayakan isi dan kelayakan penyajian. Ahli materi juga memberikan saran terkait beberapa hal, diantaranya:

1. Judul pada cover harus lebih diperjelas agar sesuai dengan isi booklet

2. Singkronisasikan antara materi dan gambar harus jelas

3. Kalimat dalam materi diperbaiki.

Menindaklanjuti penilaian dan saran dari ahli materi, maka dilakukan beberapa perbaikan. Berikut merupakan tindak lanjut dari komentar dan saran yang diberikan oleh ahli pada Gambar 5, Gambar 6, dan Gambar 7. 

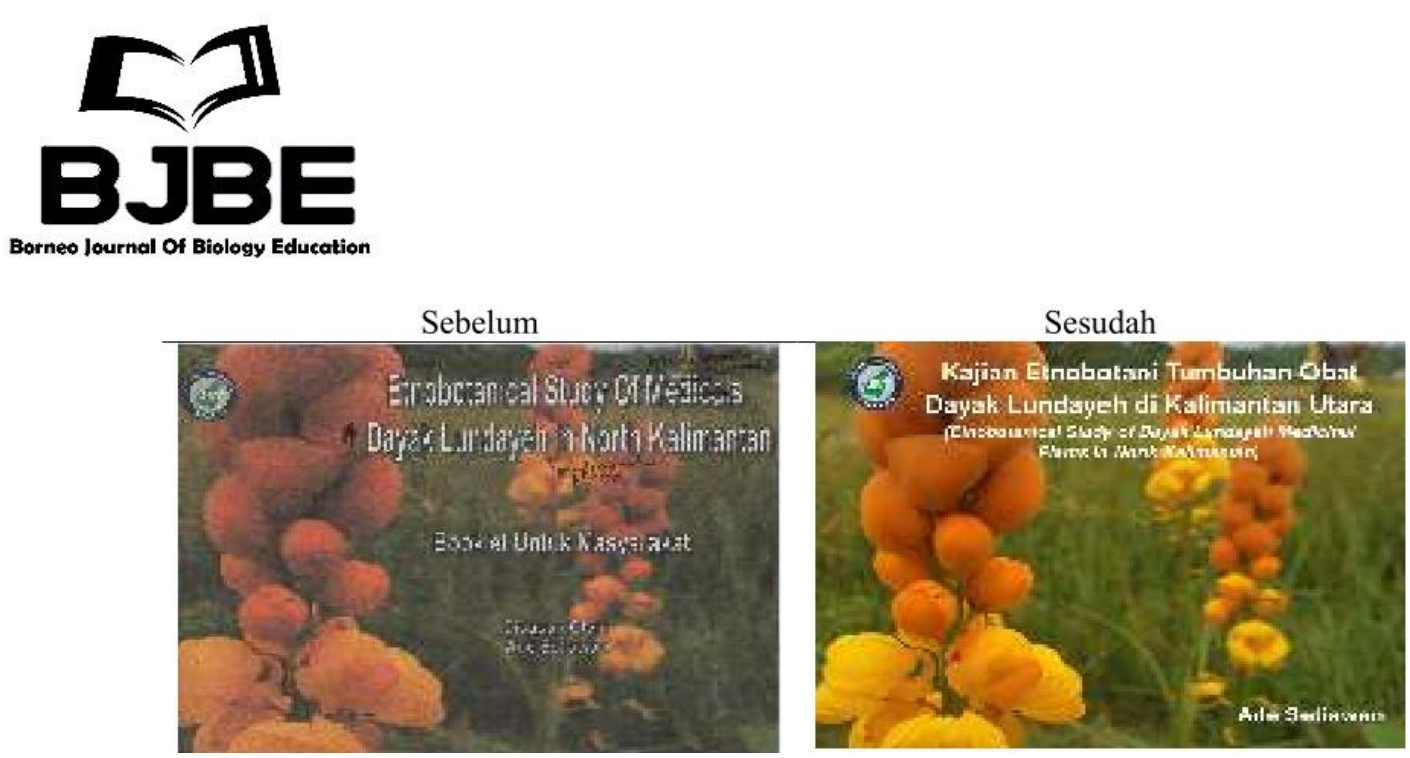

Gambar 5. Perbaikan pada Cover

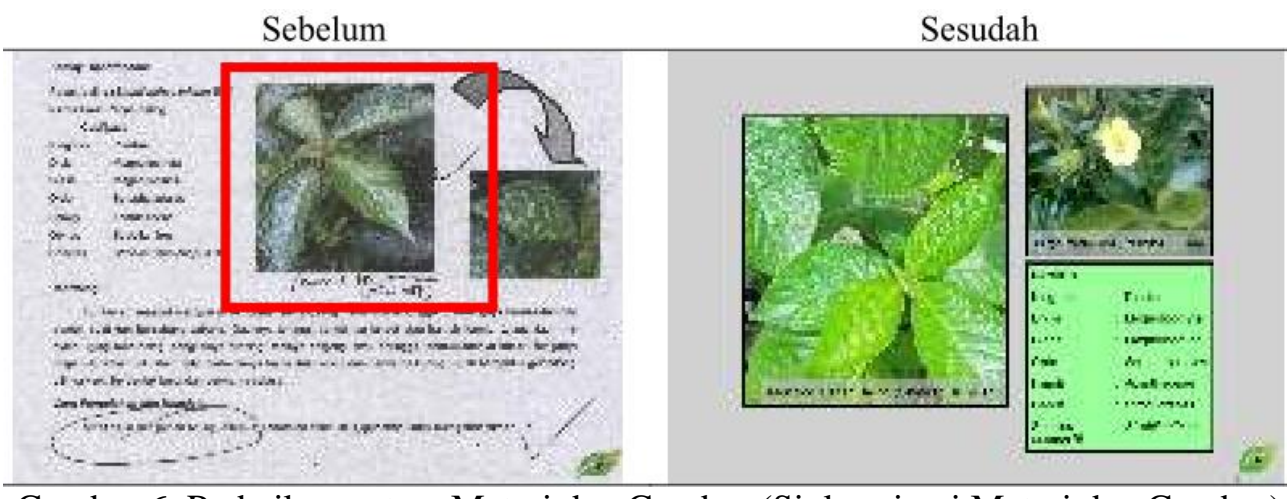

Gambar 6. Perbaikan antara Materi dan Gambar (Sinkronisasi Materi dan Gambar)

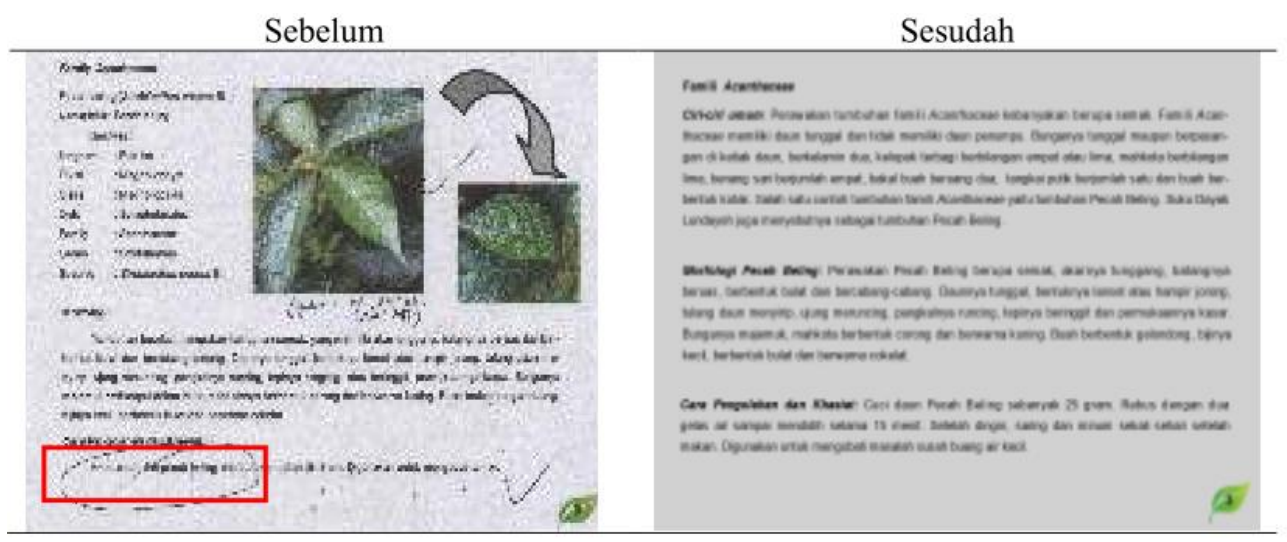

Gambar 7. Revisi Tambahan Kalimat (penjelasan)

Ahli materi memberi saran supaya judul diperbaiki agar sesuai dengan isi booklet. Judul pada booklet bertujuan untuk memberi gambaran mengenai isi booklet pada pembaca. Dewi (2014) menyatakan bahwa judul pada sebuah media digunakan untuk menarik minat dari si pembaca tersebut, sehingga sangat penting untuk memperbaiki judul dari media yang telah dibuat.

Ahli materi juga menyarankan supaya gambar dan materi harus saling terkait sehingga memperjelas materi dari booklet tersebut. Gambar digunakan agar pembaca dapat memahami isi dari booklet tersebut, sedangkan materi digunakan untuk menjelaskan gambar. Sarea (2016) menyatakan beberapa manfaat gambar yaitu: 1) gambar dapat membangkitkan minat untuk sesuatu yang baru dipelajari, 2) gambar dapat menyampaikan sesuatu dengan cara yang lebih nyata, 3) gambar dapat mengatasi ruang dan waktu. Berdasarkan pendapat 


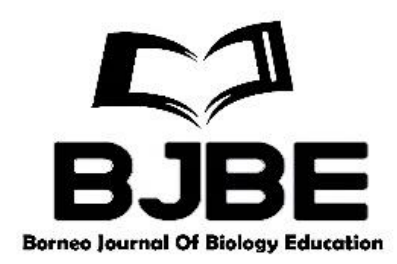

tersebut sangat penting untuk memperbaiki gambar dan materi agar tidak terjadi kesalahan memahami isi dari booklet tersebut.

Ahli materi menyarankan supaya kalimat dalam materi harus diperbaiki. Materi berisikan informasi mengenai berbagai jenis tumbuhan obat Suku Dayak Lundayeh. Kalimat yang kurang baik dapat menyebabkan pembaca salah memahami materi yang terdapat dalam booklet, sehingga perlu adanya perbaikan untuk mencegah hal tersebut. Franata (2010) menyatakan bahwa kalimat yang baik adalah kalimat yang jelas maknanya sehingga pembaca dapat memahaminya secara tepat.

Ahli media memvalidasi aspek desain kulit booklet dan desain isi booklet. Berikut merupakan hasil validasi dari ahli media yang dirinci pada Tabel 7.

Tabel 7. Hasil Validasi Ahli Media

\begin{tabular}{|l|c|}
\hline \multicolumn{1}{|c|}{ Aspek } & Persentase \\
\hline Jenis huruf yang digunakan pada kulit booklet yaitu arial. & 80 \\
\hline $\begin{array}{l}\text { Komposisi dan ukuran unsur tata letak pada kulit booklet (judul, pengarang, } \\
\text { ilustrasi, logo dan lain sebagainya) proporsional. }\end{array}$ & 100 \\
\hline Format dan jarak spasi pada isi booklet yang konsisten. & 80 \\
\hline Jenis huruf yang digunakan pada isi booklet yaitu arial. & 80 \\
\hline Ukuran huruf yang digunakan pada isi booklet adalah 8. & 80 \\
\hline $\begin{array}{l}\text { Ilustrasi dan keterangan gambar mampu memperjelas penyajian materi, baik dalam } \\
\text { bentuk, ukuran yang proporsional, maupun warna yang menarik sesuai dengan } \\
\text { objek aslinya. }\end{array}$ & 80 \\
\hline $\begin{array}{l}\text { Penempatan judul, subjudul, ilustrasi dan keterangan gambar tidak menganggu } \\
\text { pemahaman. }\end{array}$ & 100 \\
\hline Penempatan nomor halaman disesuaikan dengan pola tata letak. & 80 \\
\hline \multicolumn{2}{|c|}{ Total } \\
\hline
\end{tabular}

Komentar dan saran dari ahli media yaitu jarak atau spasi pada isi booklet harus konsisten agar mempermudah pembaca dalam memahami isi booklet (Gambar 9). Ahli media memvalidasi aspek desain kulit booklet dan desain isi booklet. Ahli media menyarankan supaya jarak atau spasi pada isi booklet harus konsisten. Spasi yang digunakan pada booklet yaitu 1,5. Lanin (2016) menyatakan bahwa spasi sangat berperan dalam meningkatkan keterbacaan suatu tulisan, sehingga sangat penting untuk memperbaiki spasi pada media yang telah dibuat.Berikut merupakan tindak lanjut dari komentar dan saran yang diberikan oleh ahli media:

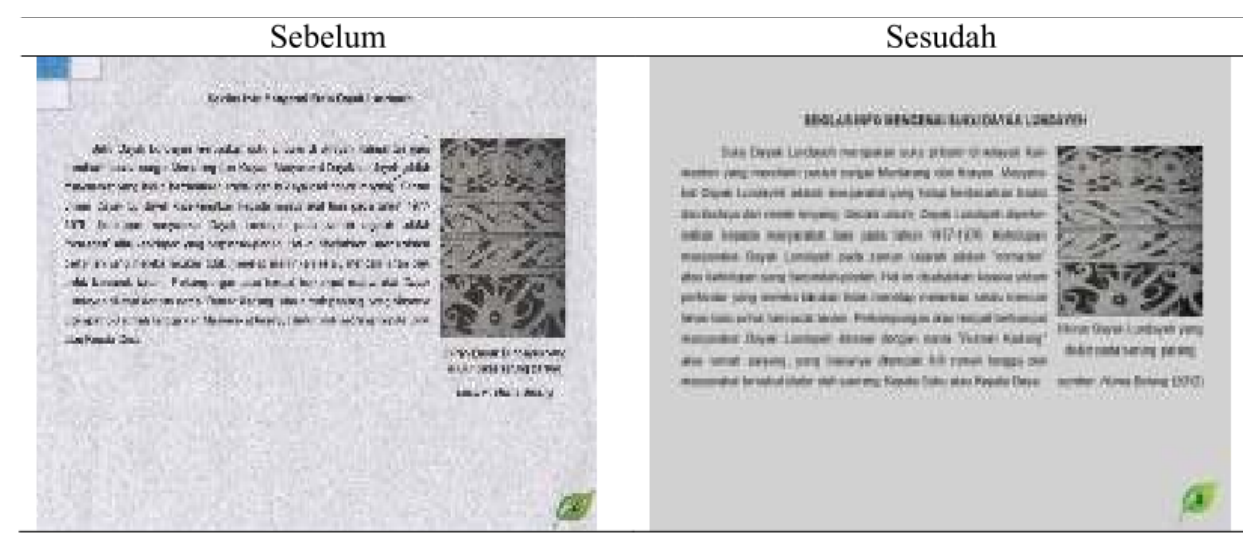

Gambar 9. Perbaikan Spasi pada Booklet 


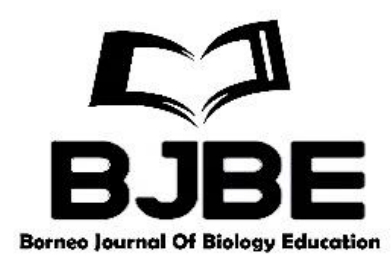

Ahli bahasa memvalidasi aspek penggunaan bahasa. Berikut merupakan penilaian dari ahli bahasa pada Tabel 8 .

Tabel 8. Hasil Validasi Ahli Bahasa

\begin{tabular}{|l|c|}
\hline \multicolumn{1}{|c|}{ Aspek } & Persentase \\
\hline Penggunaan bahasa (ejaan, kata, kalimat, istilah dan paragraf) dengan tepat dan jelas. & 80 \\
\hline $\begin{array}{l}\text { Bahasa yang digunakan komunikatif dan informative sehingga pembaca mampu } \\
\text { memahami pesan positif yang disampaikan. }\end{array}$ & 100 \\
\hline $\begin{array}{l}\text { Bahasa yang digunakan santun, etis, estetis sesuai dengan tingkat perkembangan } \\
\text { usia. }\end{array}$ & 80 \\
\hline \multicolumn{1}{|c|}{ Total } & \\
\hline
\end{tabular}

Terdapat masukan dari ahli bahasa terkait konsistensi kata dan penyederhanaan bahasa, diantanya:

1. Jika ada angka yang terdapat dalam kalimat maka untuk kesesuaian kalimat sekaligus memperjelas pemahaman pembaca, alangkah lebih baik jika ditulis dengan menggunakan huruf.

2. Bahasanya sudah baik, butuh sedikit diperhalus untuk mempermudah pemahaman pembaca.

Ahli bahasa menyarankan supaya mengganti angka dalam kalimat menjadi huruf untuk memudahkan pemahaman pembaca. Penempatan angka yang tidak tepat pada kalimat dapat mengecoh pembaca sehingga menyebabkan kesalahpahaman pembaca mengenai isi dari booklet. Dinata (2015) menyatakan bahwa angka dapat dituliskan jika angka tersebut lebih dari sepuluh agar menghindari kesalahpahaman pembaca tersebut. Selanjutnya, ahli bahasa menyarankan supaya memperhalus bahasa yang digunakan dalam booklet agar mempermudah pemahaman pembaca. Kata yang kurang atau berlebih dapat menimbulkan makna yang berbeda sehingga sangat penting untuk diperbaiki agar dapat memudahkan pemahaman pembaca. Franata (2010) menyatakan bahwa kalimat yang baik adalah kalimat yang jelas maknanya sehingga pembaca dapat memahaminya secara tepat.

\section{Uji Lapangan}

Uji lapangan awal dilakukan pada 6 orang masyarakat suku Dayak Lundayeh di Desa Kaliamok. Angket respon dari 6 orang masyarakat digunakan untuk menilai media booklet tersebut apakah sudah layak atau belum, jika sudah layak maka booklet dapat digunakan untuk uji lapangan utama. Hasil uji lapangan awal disajikan pada Tabel 9.

Tabel 9. Hasil Uji Lapangan Awal

\begin{tabular}{|l|c|}
\hline \multicolumn{1}{|c|}{ Aspek } & Persentase \\
\hline Teks atau tulisan dapat dibaca dengan jelas & 100 \\
\hline Bahasa yang digunakan dalam booklet mudah dipahami & 93,33 \\
\hline Materi yang disajikan dalam booklet sesuai dengan fakta. & 100 \\
\hline $\begin{array}{l}\text { Materi yang disajikan dalam booklet membantu memahami tentang } \\
\text { tumbuhan obat. }\end{array}$ & 100 \\
\hline Desain dari booklet menarik. & 100 \\
\hline $\begin{array}{l}\text { Materi yang disajikan dalam booklet memuat uraian, foto dan gambar } \\
\text { yang menarik. }\end{array}$ & 100 \\
\hline \multicolumn{1}{|c|}{ Total } & 98,88 \\
\hline
\end{tabular}




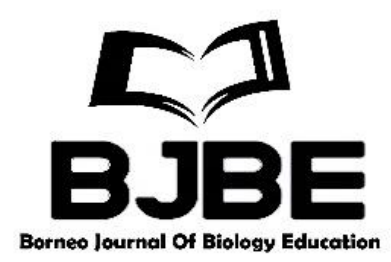

Komentar dan saran yang diperoleh dari uji lapangan awal yaitu judul pada booklet mengenai etnobotani perlu ditambahkan pada bagian isi agar pembaca memahami mengenai etnobotani tersebut.

Setelah dilakukan perbaikan berdasarkan masukan pada uji lapangan awal, kemudia dilakukan uji lapangan akhir. Uji lapangan utama dilakukan pada 30 orang masyarakat suku Dayak Lundayeh di Desa Kaliamok. Angket respon dari 30 orang masyarakat digunakan untuk menilai media booklet tersebut sudah layak atau tidak, jika sudah layak maka dapat dilakukan pembuatan produk akhir. Hasil dari uji lapangan utama didapatkan hasil 99,55\% yang berarti booklet yang dikembangkan layak digunakan.

Tabel 10. Hasil Uji Lapang

\begin{tabular}{|l|c|}
\hline \multicolumn{1}{|c|}{ Aspek } & Persentase \\
\hline Teks atau tulisan dapat dibaca dengan jelas & 100 \\
\hline Bahasa yang digunakan dalam booklet mudah dipahami & 98,66 \\
\hline Materi yang disajikan dalam booklet sesuai dengan fakta. & 100 \\
\hline $\begin{array}{l}\text { Materi yang disajikan dalam booklet membantu memahami tentang } \\
\text { tumbuhan obat. }\end{array}$ & 100 \\
\hline Desain dari booklet menarik. & 99,33 \\
\hline $\begin{array}{l}\text { Materi yang disajikan dalam booklet memuat uraian, foto dan gambar } \\
\text { yang menarik. }\end{array}$ & 99,33 \\
\hline \multicolumn{1}{|c|}{ Total } & 99,55 \\
\hline
\end{tabular}

\section{Kesimpulan}

Tumbuhan obat yang digunakan oleh Suku Dayak Lundayeh terdiri dari 21 jenis tumbuhan, yang tebagi kedalam 13 suku. Penggunaan bagian tumbuhan sebagai obat beragam, mulai dari akar, daun, dan buah. Hasil validasi dari para ahli dan angket respon masyarakat menunjukkan booklet layak digunakan dan dapat digunakan sebagai referensi untuk tahapan penelitian pengembangan lanjutan.

Saran untuk penelitian selanjutnya, booklet yang telah dikembangkan dapat dilanjutkan untuk tahap penyebarluasan ke masyarakat yang lebih luas, sehingga hasil bisa dimanfaatkan dalam berbagai bidang seperti: kesehatan, dan pendidikan

\section{Daftar Pustaka}

Abrori, F. M., Yulida, R., Adhani, A., Wijarini, F., \& Nugroho, E. D. (2016). Media Pembelajaran Biologi. Yogyakarta: Genom.

Agustin, M. (2014). Efektifitas Pendidikan Kesehatan Media Booklet Dibandingkan Audiovisual Terhadap Pengetahuan Orang Tua Tentang Karies Gigi Pada Anak Usia 5-9 Tahun Di Desa Makam Haji. Skiripsi (Tidak Dipublikasikan) Universitas Muhammadiyah Surakarta.

Anna, L.K. (2011). Merebus Herbal Pun ada Aturannya. Artikel (Online). https://lifestyle. kompas.com/. Diakses 25 Desember 2015

BAPPENAS. (2016). Indonesian Biodiversity Strategi and Action Plan. Jakarta: Dokumen Nasional Bappenas

Bell, A. D. (2001). Plant Form: An Illustrated Guide to Flowering Plant Morphology. New York : Oxford University Press 


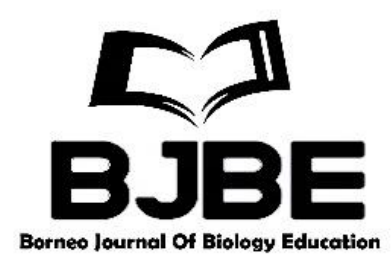

Borg, W.R dan Gall, M.D. (1983). Educational Research an Introduction. New York \& London: Longman Inc.

Dewi, M. (2014). Gaya Bahasa Media Online Di Indonesia: Judul Menarik Tidak Harus Tidak Baku (Online). Alamat Website:http://research-dashboard.binus.ac.id. Diakses 25 Desember 2015

Dinata, B. (2015). Aturan Penulisan dalam Karya Ilmiah (Online). https://bayuarsadinata. wordpress.com. Diakses 2 Januari 2016

Fitriastutik, D.R. (2010). Efektivitas Booklet dan Permainan Tebak Gambar dalam Meningkatkan Pengetahuan dan Sikap Siswa Kelas IV Terhadap Karies Gigi di SD Negeri 01, 02, dan 03 Bandengan Kecamatan Jepara Tahun Ajaran 2009/2010. Skripsi (Tidak Dipublikasikan) Univesitas Negeri Malang.

Franata, H. (2010). Penggunaan Kalimat yang Efektif dalam Penulisan Karya Ilmiah (Online). https://harrysprincenata.wordpress.com. Diakses 2 Januari 2016

Glimn-Lacy, J. \& Kaufman, P.B. (2006). Botany Illustrated: Introduction to Plants, Major Groups, Flowering Plant Families. New York : Springer

Karmilasanti \& Supartini. (2011). Keanekaragaman Jenis Tumbuhan Obat dan Pemanfaatannya Di Kawasan Tane'Olen Desa Setulang Malinau, Kalimantan Timur. Jurnal Penelitian Dipterokarpa 5 (1): 23-38.

Lanin, I. (2016). Peran Spasi dalam Tulisan (Online). https://beritagar.id/. Diakses 25 Juni 2016

Listiani, L., \& Abrori, F. M. (2019). Ethnobotanical Study on Tidung Tribe in Using Plants for Medicine, Spice, and Ceremony. IPTEK The Journal for Technology and Science, 29(1), 18-24.

Nurjannah, S, Zuhud, E.A.M, \& Prasetyo, L.B. (2015). Sebaran Spasial Tumbuhan Obat Yang dimanfaatkan Masyarakat Kampung Nyungcung, Desa Malasari, Kecamatan Nanggung, Kabupaten Bogor. Jurnal Media Konservasi 20 (3): 205-210.

Purwanto, M.N. (2009). Prinsip-Prinsip dan Teknik Evaluasi Pengajaran. Bandung: PT Remaja Rosdakarya.

Rahayu, M, Sunarti, S, Sulistiarni, D, \& Prawiroatmodjo, S. (2006). Pemanfaatan Tumbuhan Obat secara Tradisional oleh Masyarakat Lokal di Pulau Wawonii Sulawesi Tenggara. Jurnal Biodiversitas 7 (3): 245-250.

Sarea, S. (2016). Media Gambar: Pengertian, Fungsi serta Manfaat. (Online). https: //www.wawasan pendidikan.com/ . Diakses 6 Maret 2016

Sugiyono. (2015). Metode Penelitian Kuantiitatif, Kualitatif dan R\&D. Bandung: Alfabeta.

Suhartini. (2009). Peran Konservasi Keanekaragaman Hayati dalam Menunjang Pembangunan yang Berkelanjutan. Prosiding Seminar Nasional Penelitian, Pendidikan dan Penerapan MIPA. Universitas Yogyakarta.

Syamsir, E. (2015). Budidaya Tanaman Obat. Bogor: SEAFAST Center IPB.

Van Steenis. C.G.G.J. (2006). Flora. Jakarta : Pradnya Paramita

Washikah. (2016). Tumbuhan Zingiberaceae Sebagai Obat-Obatan. Jurnal Serambi Saintia 4 (1): 35-43. 